This is a post-peer-review, pre-copy edited version of an extract/chapter published in Madgin, R. \& Kintrea, K. (2019) Transforming Glasgow: People, Place and Policy - Beyond the Post-Industrial City. Bristol: Policy Press. Details of the definitive published version and how to purchase it are available online at:

https://policy.bristoluniversitypress.co.uk/transforming-glasgow

\title{
Changing Places and Evolving Activism: Communities in Post-Industrial Glasgow
}

Steve Rolfe, Claire Bynner and Annette Hastings

\begin{abstract}
This chapter explores the interactions between the changing nature of Glasgow and contemporary community activism. Utilising three case studies of community activism in very different neighbourhoods, we investigate the ways in which differences in community history and capacity, as well as relations with the local state, shape forms of activism. Examining local activism in this way helps to understand and explain the boundaries and nature of communities within the city, and provides insights into complex processes of deindustrialisation and urban change, which have transformed Glasgow in recent decades. Whilst there are changes emerging from rapid demographic shifts in some areas and the growth of online activism, the wider picture is one of evolving continuity, as Glasgow's long history of community activism persists into the $21^{\text {st }}$ century.
\end{abstract}

\section{Keywords}

Community activism; community participation; neighbourhoods; inequality; diversity

\section{Introduction}

Glasgow's history through the $20^{\text {th }}$ century and into the $21^{\text {st }}$ is one of immense changes in places, neighbourhoods and communities. From the slum clearances and creation of peripheral estates, through to contemporary changes such as the Red Road flats demolition and the building of the Commonwealth Games Village, whole areas of the city have been transformed, often more than once. More recently, some parts of the city have also experienced rapid increases in diversity, changing the social and cultural character of the city and in low income neighbourhoods adding new dimensions to the persistent levels of poverty and inequality for which the city is sadly infamous. 
This chapter examines contemporary community activism in Glasgow in the light of this history and continuing changes in the city. Through three case studies of community activism in different neighbourhoods, we explore the interactions between community characteristics, forms of activism and aspects of transformation across the city.

Whilst the forms of community activism are as varied as communities themselves, it is possible to delineate three broad categories (Rolfe, 2016). Firstly, the form of community activism with the longest pedigree is mutual self-help, whereby communities provide material or emotional support through informal networks or formal service-providing organisations (Somerville, 2011). Secondly, communities can attempt to influence services and address local issues by means of independent political activism, also described as social action (Crisp et al., 2016). And lastly, communities may engage in forms of democratic participation, acting in ways which enhance representative democracy (Barnes et al., 2003) or complement it through participative or deliberative processes (Escobar, 2017).

Importantly, exploring the interactions between the changing nature of Glasgow and contemporary community activism necessitates an understanding of not just the concept of community activism, but also the nature of community itself. This is far from simple since 'community' is a complex and elusive concept, descriptively encapsulating elements of locality and belonging, as well as shared interests and values, whilst also retaining a reassuring normative veneer (Plant, 1974: 10-14). Moreover, the somewhat amorphous nature of community is more difficult to grasp in a context of change, where physical regeneration or transitory populations alter the nature of neighbourhoods and networks of common interest (Somerville, 2011: 1-3). Indeed, longer term narratives of community tend to suggest that communities are not merely changing, but also being eroded over time. Often this is presented as a 'loss of community', connected to a shift from close-knit rural communities in the pre-industrial age to atomised individuals in urbanised, industrial modernity (Tonnies, 1955). Although, others argue that the growth of individualisation may also be a form of liberation, particularly for individuals ostracised by the conservative values of traditional communities (Dahrendorf, 1968).

Hence theorisations of community tend to be associated with the advent of industrialisation and urbanisation. This chapter explores the extent to which these changes have been reinforced or altered by deindustrialisation and whether it makes sense to talk of 'post-industrial' communities. Focusing on community activism provides a useful lens to help us understand these changes in 
communities, since examining collective action reveals the underlying networks, shared values and socio-demographic boundaries from which community emerges. Thus, community activism can provide an indicator of the shape and health of communities within the city, illuminating the ways in which broader physical, demographic and socio-economic changes are experienced at the local level.

These debates about the changing nature of communities are vital context to understand the development of policies which focus on community in the post-industrial urban environment. From the 1960's onwards, factors such as the 'rediscovery' of poverty and concerns about urban unrest (Somerville, 2011), together with growing doubts about 'expert' solutions to wicked social problems (Boaden et al., 1981), have led governments of all political hues to develop policies focused on community participation, development or empowerment. Thus, communities have been seen as both a problem, particularly in terms of the supposed 'loss of community', and a solution, as a locus of collective response to social issues and service failures (Hancock et al., 2012). This emphasis on community within social policy is evident internationally in fields such as economic and local development (United Nations, 2008; European Union, 2011), whilst the UK has witnessed multiple attempts to engage communities, particularly in relation to urban regeneration, partly in response to the challenges of urban deindustrialisation (Green and Chapman, 1992; McWilliams et al., 2004; Batty et al., 2010). Notably, more recent UK policies have broadened the goal of engaging communities beyond regeneration into a wider range of public policies (UK, 2007; UK, 2009; UK, 2011), and this trend is perhaps even stronger under the devolved administrations in Scotland, culminating in the Community Empowerment Act (Scotland, 2015). Thus, successive governments in Westminster and Holyrood have developed policy which aims to develop, engage and empower communities, envisaging community activism as a panacea for concerns about the loss of community and limitations of top-down public services.

Importantly, the form which community activism takes at particular times and places is determined by key factors within the community, alongside external pressures and opportunities, including national and local policy frameworks. Inequalities in the capacity to participate and benefit from community empowerment across localities have been increasingly recognised (Steiner and Farmer, 2018), given variations in communities' resources, organisational capacity, and internal cohesion and connectedness (Brodie et al., 2009). Moreover, these community characteristics are never static, particularly in situations where neighbourhoods are experiencing significant change through physical regeneration (Jones and Evans, 2013) or complex processes of shifting demography and socioeconomic conditions (Bynner, 2017). Hence the individual and collective tactical choices of 
community members are affected by their experience of neighbourhood and community change (Kearns et al., 2019). Alongside this, the 'spaces for participation' (Gaventa, 2006) are shaped by the policy and practice of local and national government, and the complex relationships between communities and local public sector bodies (Rolfe, 2018). Thus, in some instances, communities may be 'invited' to participate by public authorities, whilst in others they may need to 'claim' their own spaces for participation (Dean, 2017). Notably, these questions of differences between communities in terms of capacity for activism and differences in the available spaces for participation underlie critiques directed at community participation policies and practices. Whilst community activism is often presented as an opportunity for 'empowerment' (not least in policy rhetoric), there are concerns that disadvantaged communities are required to do more in order to claim collective rights (Flint, 2004), and risks that participation can become a form of tyranny (Cooke and Kothari, 2001) or an unwelcome shift of responsibility from the state to communities (Imrie and Raco, 2003). Moreover, in a context of austerity and the retrenchment of public services (Peck, 2012), there are questions as to whether the state at local and national levels acts to enable community empowerment or withdraws from the stage in a laissez-faire fashion, with potential implications for inequalities between communities (Parker and Street, 2015).

Understanding community activism within the transforming city of Glasgow, therefore, requires an examination of the ways different communities take action in response to different types of change and how the forms that activism takes are shaped by interactions with the local and national state, the local context of the neighbourhood and city, and the broader socio-economic situation.

\section{Background - Community Activism in Historical Context}

Glasgow's long history of activism is often portrayed like a highlights reel - a set of distinct moments of political radicalism from Red Clydeside in the early $20^{\text {th }}$ century through the Upper Clyde Shipbuilders 'work-in' in the 1970s, to the emergence of the Scottish Socialist Party from the Poll Tax protests in the late 1980s. To an extent, this narrative is connected to processes of deindustrialisation, especially those re-structuring the city's economy and labour market. There are also less well-known narratives which emphasise myriad forms of small-scale, local activism - also in response to processes of post-industrial transformation - but here focused on how transformation is experienced and engaged with in residential neighbourhoods. 
While the focus of the chapter is on contemporary urban transformation, it is worth briefly outlining the history of how local communities in Glasgow have shaped or responded to neighbourhood change, and how this relates to the three forms of activism identified in the Introduction.

Traditions of workplace political activism, where trade unionists and educated elites joined with the communities directly affected, have also been important in relation to neighbourhood change whether this change has been perceived as exploitative, ideological or simply unwelcome. The mobilisation of women who refused to defer to rapacious private landlords in the Great Rent Strike of 1915 (Lavalette and Mooney 2000) is a well-known early example, as was the political resistance in the 1990s which framed the transfer of the city's municipal housing stock to a new city-wide housing association as incipient privatisation (Mooney and Poole, 2005). Local communities have engaged in political campaigns opposing substantial changes to the urban form designed to address, for example, population loss - such as protests mounted to save large scale, high rise public housing estates in the Sighthill and Red Road areas from demolition (Leslie, 2016); or infrastructure development - the 'heritage' framed protests in the city's affluent, west end neighbourhoods (Gomme and Walker, 1968).

In relation to self-help models of activism, Glasgow's community-based housing association (CBHA) movement stands out as an example of a service provider form of self-help. However, it should be acknowledged that CBHAs are part of a historic, broader tradition of co-operative self-provision of supportive services for children and young people, parents, the unemployed and the retired services lacking in many of the new public housing estates developed in the city's post-war transformation (Hastings et al, 1996). Indeed, the CBHA movement developed from political activism: resistance to the demolition and displacement of historic inner-city working class neighbourhoods. From the mid-1970s on, a conducive policy and resource environment allowed this activism to evolve into the development of a large number of nationally regulated, but neighbourhood focused housing organisations, in which management committees of local residents worked with paid staff to manage and deliver substantial physical and social change in working-class neighbourhoods (Clapham et al, 1996). It is important to note, however, that this initially radical selfhelp movement quite quickly became instrumentalised by government. In the late 1980s and early 1990s, setting up a housing association became a pre-requisite to accessing housing investment in municipal housing neighbourhoods across the city (McKee, 2007). 
Finally, residents of Glasgow's neighbourhoods have been engaged in forms of democratic participation developed since the late 1980s under various guises. Historically, in working-class and disadvantaged neighbourhoods, participation has tended to go beyond the statutory mechanisms for democratic engagement in local decision-making on offer - such as Community Councils and Community Planning partnerships - to become part of state sponsored 'regeneration' focused interventions. Over time the nature and extent of participation has not necessarily progressed towards more substantial engagement - although less tokenistic forms of participation may have become more of the norm. Early initiatives in the Easterhouse and Drumchapel neighbourhoods afforded local residents only the role of "observers" at meetings, required to sit apart from other participants (Hastings et al, 1996). Indeed, some early forms of democratic participation provided local residents with long sought platforms to voice concerns. For example, community organisations in Castlemilk greeted the announcement of the New Life for Urban Scotland neighbourhood regeneration initiative with protests highlighting that 'poverty is the issue' and by withdrawing their support until issues such as community safety and local shopping were allowed onto the initiative's agenda (Hastings et al, 1996). Since the 2000s, there have been new democratic participation opportunities for some, through a stronger focus on engagement beyond the 'usual suspects' and innovations developed elsewhere, such as participatory budgeting.

In the next section we examine three very different case studies of community activism in contemporary Glasgow, selected to illustrate the diversity of community responses to the transforming nature of the city and its neighbourhoods. The case studies are drawn from intensive research within each neighbourhood, involving interviews, focus groups, documentary analysis and participant observation.

\section{Box 1 - Outline of case study areas}

\section{Dowanhill}

The adjoining neighbourhoods of Dowanhill, Hyndland and Kelvinside (referred to here as Dowanhill) in Glasgow's West End form one of the most affluent areas of the city, with much higher levels of income and education and lower levels of unemployment than the Glasgow average (Glasgow Centre for Population Health, 2017). The area consists of villa-style properties and tenements, primarily in owner-occupation with a minority of privately rented flats, largely occupied by students at the nearby University of Glasgow. Whilst the student population adds an element of transience and diversity, the community is relatively homogeneous, being largely middle-class and less 
ethnically diverse than Glasgow as a whole (Glasgow Centre for Population Health, 2017). Unlike other areas of the city, the predominance of owner occupation and lack of vacant land in this area means it has experienced relatively little physical or social change in recent decades.

\section{Oatlands}

Oatlands is a relatively small neighbourhood which, at the time of the research, could be characterised as being in transition. Historically, the area consisted of local authority housing, with a relatively high level of socio-economic disadvantage. From the late 1990s a dramatic regeneration plan was instigated, demolishing the pre-existing housing and constructing a new neighbourhood comprised of social and private sector housing through a deal between the local authority and a private housing developer. At the time of the research, the mix of housing tenure was approximately 50-50, with around 200 social housing properties, let primarily to long-standing residents of the area, and a similar number of private properties, but the long-term plan includes around 1100 private properties (Glasgow City Council, 2016). The area is therefore undergoing transition in terms of physical appearance, population size and socio-economic mix.

\section{Govanhill}

Govanhill is a super-diverse neighbourhood located in the south side of the city where long-settled white and ethnic minority communities reside alongside Central and Eastern European Roma migrants, asylum seekers and refugees, and other recent arrivals (Bynner 2017). The 2011 census data shows an ethnic minority population of $33 \%$ compared to the city average of $11 \%$ (Glasgow Centre for Population Health, 2017). At a local level, the diversity is most starkly indicated by a local primary school with over 57 different home languages spoken by pupils (ODS 2013). Govanhill has a relatively young population with economic activity close to the city average. The area's housing is characterised by mixed tenure, older, tenement housing, with some parts of the private rented housing being in extremely poor condition. The neighbourhood includes datazones that are amongst the most housing deprived in the city (Scottish Government 2017).

The fieldwork took place between 2012 and 2015 - descriptions of the areas and community organisations relate to this period. Whilst there have been further changes in the areas since (particularly in Oatlands, where further house-building has now been completed), the evidence from this period in the three communities provides examples of processes which are neither unique to these parts of Glasgow, nor simply reflective of their time. For example, there are clear parallels 
between the Oatlands experience of complete demolition and replacement of social housing with ongoing changes in other mixed tenure estates elsewhere in Glasgow.

\section{Case study 1 - Dowanhill, Hyndland and Kelvinside}

Central to activism in Dowanhill is the Community Council, which has a membership of 20 people from across the area, elected by a population of approximately 14,000. Community Councils are the most local tier of statutory representation in Scotland, whose primary purpose is to 'bridge the gap between local authorities and communities' (Scottish Government, 2014) by ascertaining the views of their community and expressing them to the local Council and other bodies. They have statutory consultation rights on planning and licensing applications and are often consulted by local government and other public agencies on other matters.

As a formally constituted body, it is perhaps unsurprising that the Community Council's approach to activism was primarily one of formal democratic participation. Observations of their meetings over two years highlighted the extent to which the organisation took its statutory responsibilities very seriously, closely monitoring all planning and licensing applications, submitting comments on any considered inappropriate or inadequate. Alongside this, the Community Council was in almost constant communication with the local authority and other agencies regarding other local issues, from litter and graffiti, to traffic issues and houses in multiple occupancy.

Running through the Community Council's work was a central focus on maintaining the local area, ensuring that the relatively high standards of architecture, heritage, amenity, cleanliness and safety were protected and therefore resisting significant change to the area. Thus, planning applications, litter levels and potholes were all subject to 'eternal vigilance', as one Community Councillor described their approach. Moreover, this constant attention to detail was combined with a sense of persistent external threat arising from profit-hungry developers, self-interested home-owners and failing public services, such that maintaining standards extended into a target of 'putting things back to where they ought to be' (Community Councillor). This emphasis on retaining the character of the area was also reinforced by close relations with another local association working to protect the Victorian and Edwardian architectural heritage of the wider West End.

Notably, the Community Council's approach in addressing local issues was shaped not merely by this focus on maintaining standards within the area, but also by a sense of its distinctive nature within Glasgow and the implications of this distinctiveness for relationships with the local authority. Whilst 
there was a recognition amongst Community Council members that other areas of the city face significantly greater challenges and that the City Council will prioritise areas with the highest level of need, members also expressed concern that this created bias against articulate, middle-class voices. Moreover, this concern was wrapped up with a wider impression of the City Council as being characterised by inept paternalism, described by one Community Councillor as 'corruption cloaked in incompetence'.

On the other side of the fence, evidence from a Council officer illustrated a kernel of truth within these doubts, expressed in the view that loud voices from some Community Councillors could easily dominate debates, without necessarily being representative of wider community views:

'it's not that we doubt what they're saying, but we want to try to facilitate that the views they express are as genuinely representative of the wider community as we can...I think experience and history will show that Community Councillors sometimes come along and almost forget that they're representing the area. They can make good and valid contributions - I'm not demeaning that for a moment, but sometimes it's those that shout loudest on hobby horse type issues.' (Council Officer)

This sense of mutual suspicion generated a complex working relationship between the Community Council and the local authority. Whilst the Community Council maintained close ties with local Councillors and had built effective connections with some officers, these relationships were strategic, driven by constant concern to monitor slippage in service standards and take every opportunity to lobby for local improvements.

These subtle tensions with the local authority were particularly highlighted by City Council attempts to shift towards a model of co-production and shared responsibility in the context of budget cuts:

'We're trying to...break that dependency culture that's built up, or expectation culture. You know - litter's there, the Council will sort that. Yes, we are definitely part of the solution, but equally so are they.' (Council officer)

Most Community Councillors viewed these ideas with immense suspicion, to the extent that individual members who had cleared litter from their own street were explicitly criticised for doing work which should be the responsibility of the local authority. 
Thus, the Community Council in Dowanhill demonstrated a clear focus on maintaining the character of their well-established neighbourhood, preserving the distinctiveness of the area within Glasgow by strategically managing complex relationships with local agencies, particularly the local authority. Whilst their approach was significantly driven by a perception of external threat to the area, the level of change was clearly far lower than that experienced in many parts of the city, as illustrated in the other case studies in this chapter. And notably, despite pressures to shift towards more community self-help, the Community Council maintained their central tactic of democratic participation, relying on their skills, confidence and connections to generate sufficient influence.

\section{Case study 2 - Oatlands}

The primary community organisation in the area, Oatlands Development Trust, was established following a public meeting run by the local authority, with significant early support from Council officers. The Council's intention was that the Trust could take on a church building (one of only two pre-development buildings in the area) as a community centre, replacing the existing temporary hut. The board of the Trust consisted of a mix of long-standing and new residents. Whilst the Trust had adopted the Council's plan for the church in the long term, their more immediate activities were focused on community development, including developing a play park, running community events and publishing a community newsletter.

The Trust's approach to community activism was therefore primarily one of self-help, driven by two inter-related factors. Firstly, there was a clear sense that the local authority was keen to pass responsibility for some issues on to the community. And secondly, there was a recognition that the basic work of developing a cohesive community might not be a task for the state, given the history of Council failures as the landlord and the subsequent top-down restructuring of the neighbourhood.

Importantly, the focus of this approach was also driven by the drastic changes in neighbourhood population, particularly a concern to compensate for the continual upheaval of the redevelopment, and to overcome potential divisions within the community, given the mix of social housing tenants with a long history in the area, and incoming owner-occupiers and private sector tenants. Thus, the Trust saw the investment of time and energy in the play park project as essential: 
'The community deserves such a thing - the community has been through quite a lot, both the previous community and the one that's emerging. The investment of that money is a drop in the ocean compared to the benefits they'll get from it.' (Trust board member)

At the same time, however, these issues of division and change also created challenges. Whilst many residents welcomed the play facilities and community events, some long-standing community members appeared to resent the role of newcomers, albeit that the board was deliberately constituted of old and new residents. This community division was also reflected in complex relationships with the local authority, creating challenges in developing positive relationships with local Councillors, some of whom had strong relationships with existing community activists not involved with the Trust.

Alongside this, the Trust's approach was also shaped by wider changes as the timescale for the development of the remaining housing and other amenities had changed radically after the Global Financial Crisis, with the completion date of around 2015 being pushed back to around 2030. Thus, community concerns shifted towards the pace of development and delays in funding for community facilities, which should have been released as part of the development plan.

Hence the approach of the Development Trust in Oatlands was significantly shaped by the imposed top-down regeneration process which was radically changing the nature of the local community, complicated by the impacts of wider structural forces. Whilst self-help activities were, to some extent, a choice driven by the need to build the new community from the ground up, the Trust also recognised the impossibility of using more formal democratic participation methods to achieve their aims given the context of historical local authority failings and difficult relationships with some parts of the Council. Thus, whilst the Council officer responsible for the regeneration programme highlighted the 'super degree of additionality' provided by the Trust's work, internally one Trust member emphasised resentment at being left to 'do the Council's job' in providing community facilities.

\section{Case study 3 - Govanhill}

In 2007, the Govanhill Residents Group was set up in response to escalating social and racial tensions in the neighbourhood and declining physical and environmental conditions. The group provided a vehicle for democratic participation, initiated by residents in response to these challenges. Initially, 
young professionals and long-settled residents, including Scottish Asian and Scottish-Irish residents, attended the group's meetings. Officers from Glasgow Community Safety Services organised and administered the meetings. They received, logged complaints, and referred issues to the relevant services.

After a few years, the officers encouraged the group to become an independently constituted community group with charitable status. This, they argued, would give residents greater ownership and the ability to apply for funding for local projects. After the group become constituted a new committee was formed and support from the officers was withdrawn, signalling a shift to self-help community activism.

Whilst the initial focus of the group was to put pressure on public services to respond to escalating neighbourhood problems, members of the new committee felt that this complaints-focussed approach had become reactive and negative. Residents repeatedly raised the same issues at meetings regarding landlord practices, the behaviour of neighbours, litter and dumping, and residents were disheartened by the lack of progress. An early decision of the committee was to change the focus of the group from complaints about local services, to self-help projects such as community clean-ups and community gardening. As the focus of the group changed, involvement from long-settled white and Scottish Asian residents declined and the membership became almost exclusively middle-class homeowners. One member reflected on the homogeneity of the new committee:

'At the meetings it is always bloody us. It's like the sort of 30-40 somethings, owner occupiers, readers of the Guardian, liberal lefties...' (Liberal Homeowner, white Scottish, female, aged 38, group interview)

Another committee member explained 'we were more than open to other folk coming in, but that's how it ended up'. This resident reflected that in practical terms self-help community activism was easier with people who were 'like-minded', with knowledge of 'how systems work':

'They are capable of being assertive and pushing things forward, because of their education and because of their interests. So professional people who are able to grasp systems and take advantage of whatever is out there.' (White Scottish, female, aged 51, individual interview) 
The preference for self-help community activism amongst middle-class members of the Residents Group was strengthened by their social networks and connections to projects such as the Streetland Arts Festival and the restoration of the Govanhill Baths, one of Glasgow's last Edwardian Bathhouses.

As the Residents Group began to decline in numbers, another community group rose to prominence through social media-based community activism. In 2013, a woman in her 20s began the 'Restore Govanhill' Facebook campaign. She described her motivation as concern for the safety of her neighbours and a desire to challenge the behaviour of particular migrant groups:

'It's not so much that we have a problem with them because they are Eastern European, its that we have got a problem with behaviour. The way they are treating the place and treating their neighbours, certain people in that community. So, I knew it would be difficult. It's a difficult thing to word as well. You know what it is, but I think it's difficult for people to put it into words without it sounding racist.' (Mixed ethnicity, Scottish, female, aged 25, individual interview).

The focus of the public debate on social media was on conflicting narratives of community and diversity. For long-settled working-class members of Restore Govanhill, 'community' was a strongly emotive form of place-based identity and collective belonging expressed through shared memories and nostalgia for the past. For the middle-class members of the Residents Group 'community' was enacted and achieved through inclusion and participation in civic life. Those in support of the older, nostalgic Govanhill community were accused of being 'racists' and 'Roma-phobes' and in return, the pro-diversity activists were criticised for being 'do-gooders' with 'rose-tinted glasses'. The outcome was sharp political and social division framed as a moral conflict between the 'racists' and the 'antiracists'. Increasing antagonism between these groups led to all residents withdrawing from democratic participation on neighbourhood issues including Scottish Asian, Roma, and other global migrants.

This case suggests that in the post-industrial city there is a risk of over-reliance on community organisation and self-help activism to respond to local effects of globalisation. In Govanhill, the global economic and population dynamics driving neighbourhood change, as well as the long-term effects of housing de-regulation and traditional, poor quality housing, were beyond the scope of 
small-scale community projects and volunteerism. The absence of an effective mechanism for democratic participation or an inclusive form of political activism undermined the potential for residents to challenge the wider causes of poverty and insecurity in Govanhill.

\section{Discussion and Conclusion}

Whilst these case studies do not represent a complete picture of community activism across Glasgow, they nevertheless offer important insights into the diversity of activism across the city. Although it is possible to envisage future instances of large-scale, city-wide activism akin to Red Clydeside or the Poll Tax resistance, most activism is local and is therefore shaped by differences in communities and their context. The forms that community activism takes speak to wider understandings of community activism and the nature of community, which in turn have implications for debates around the conception of the post-industrial city.

Looking across the case studies, it is evident that the substantial differences in capacity between and within communities play a significant role in the forms of activism adopted. Differences in human resources and organisational capacity (Brodie et al., 2009) clearly enable more advantaged communities such as Dowanhill, or sections of communities, such as those involved in the Govanhill Residents Group, to utilise 'invited' spaces (Gaventa, 2006) for democratic participation, where others may struggle. Inequalities are also important beyond community capacity, since such capacity needs to be weighed against the level of challenge faced by different communities. Whereas Dowanhill Community Council tackled many local issues through conversations with officers or Councillors, the much greater challenges arising in the more disadvantaged area of Govanhill were far more difficult to fix through democratic influence, even for the articulate middle-class voices of the Residents Group. Furthermore, the community capacity available in neighbourhoods such as Dowanhill enables activists to avoid the risks of co-option by maintaining a critical distance from the state (Watkins, 2017), even as they work closely with public bodies, therefore limiting the degree of 'responsibilisation', where responsibilities and risks are transferred from the state onto communities (Rolfe, 2018).

The wider context also shapes the opportunities for different forms of activism and the choices that community groups make. The political opportunity structure (Maloney et al., 2000), within which communities make choices about activism, can be altered by structural forces such as the impacts of the Global Financial Crisis. As the Oatlands case demonstrates, opportunities for achieving change 
through democratic participation may be restricted by financial constraints on both public and private sectors, making self-help a more attractive and effective option to deliver community facilities. Whilst the Scottish Government's Community Empowerment agenda represents an ambitious framework for community activism, this evidence suggests that wider structural constraints may undermine such policy aspirations (Rolfe, 2018).

Perhaps ironically, the impact of the Global Financial Crisis in Oatlands also affected another important factor influencing community activism, by slowing the pace of population growth and change. This contrasts with the Govanhill experience of rapid demographic change over the last decade. Whilst the Development Trust in Oatlands has at times struggled to build a new community, both groups in Govanhill have faced even greater challenges related to attitudes towards diversity and community cohesion, restricting their capacity to present a unified voice and therefore utilise formal democratic opportunities. Community activism does not require homogeneity, but it can clearly be restricted by lack of community cohesion. In particular, challenges of maintaining inclusiveness within community groups formed in very diverse, fast changing neighbourhoods can undermine their effectiveness by limiting the human resources on which they can draw, and through public bodies being unwilling to work with groups perceived as divisive and exclusive (Blake et al., 2008).

The local state also plays a central role in shaping the political opportunity structure for community activism, most obviously through the creation of invited spaces for democratic participation, but also through responses to different forms of activism. In particular, relationships between community activists and local authorities are crucial in shaping activists' perceptions of the value of different approaches. Thus, Restore Govanhill's perception that the local authority was failing to act as a neutral arbitrator between competing views and was ineffective in tackling material decline led them to a strategy of political activism, whilst Oatlands Development Trust's view of the limitations of Council efforts to develop communities inclined them towards self-help. Notably, these issues interact again with inequalities in community capacity - whilst Dowanhill Community Council were frequently critical of local authority efforts and concerned about bias towards more disadvantaged areas, they had sufficient belief in their own sharp elbows (Matthews and Hastings, 2013) to sustain an effective approach of influencing through formal democratic channels. By contrast, the Govanhill Residents Group believed they could create more impact by working with 'like-minded folk', effectively narrowing their membership to a middle-class core, but this undermined their longevity thanks to the lack of formalised structure (such as a Community Council) and Govanhill's population 
instability, as active members moved away. Again, examining these dynamics at the level of communities and the local state is essential in understanding whether and how national policy such as the Community Empowerment agenda plays out in practice.

These diverse examples of activism from across Glasgow suggest that the notion of 'loss of community' is, at the very least, exaggerated. The fact that people in each of these areas have come together to collectively address local issues suggests that contemporary neighbourhoods retain a sense of community, and one that can be converted into action. Although, the differences between the case studies suggests that the strength and shape of communities can be heavily influenced by persistent inequalities and by often externally-imposed transformational change in neighbourhoods and populations. In this respect, examining community activism clearly offers a productive lens through which to understand the boundaries and nature of particular communities, helping to delineate the geographic areas, demographic or interest groups with which people most identify. Communities are changing rather than 'lost' and the detailed exploration of local activism can help to explicate the nature of these changes and elucidate their implications for policy and practice.

Moreover, looking across the case studies provides interesting insights into the complex, non-linear processes of deindustrialisation and urban change in a context of 21st century globalisation. Whilst physical regeneration projects such as the rebuilding of Oatlands can be seen as part of the longterm fallout from Glasgow's experience of deindustrialisation, unemployment and neighbourhood decline, Govanhill's recent demographic change arguably has roots in similar processes in Eastern Europe. Thus, global economic factors have pushed disadvantaged populations in differing directions, creating novel challenges for activists attempting to build and energise communities. Whilst more affluent areas such as Dowanhill are not unaffected by the wider changes in the global economy, the evidence from these case studies highlights the depth of inequality which was entrenched by the late 20th century experience of deindustrialisation and persists in the putatively post-industrial city, shaping the opportunities for and outcomes of community activism.

In terms of Glasgow itself, there is a significant degree of continuity in terms of both the diversity of activism and the frequently complex, conflictual relationships with the local state. In particular, the sense that communities are often responding to radical physical and material change to housing and the built environment and to fears of such externally-imposed change, shown in the earlier examples of opposition to stock transfer, demolition or loss of heritage, echoes through all three neighbourhoods. At the same time, however, there are also newly emerging elements to this 
activism, such as the development of social media-based activism and the difficult interactions between activism and levels of demographic super-diversity not previously experienced.

Such a picture suggests that community activism will be a continuing feature of Glasgow's neighbourhoods and an important part of the city's process of transformation, although the forms of activism are likely to evolve along with the city. Community activism is clearly linked to the socioeconomic, physical and demographic changes occurring in a city which has perhaps moved beyond the immediate effects of deindustrialisation but continues to be buffeted by the winds of 21st century globalisation. Indeed, the sense of diversified forms of activism and divergent experiences of neighbourhood change suggest that the micro-local may be increasingly important as a site of activism. This both reflects and potentially exacerbates widening socio-spatial inequalities. Hence there is a paradox of growing participation and growing inequalities (Lee et al., 2015) and a risk that participation of all varieties will be skewed in favour of those with higher socio-economic status and formal education (Ryfe and Stalsburg, 2012). In this context, therefore, the question of whether the ambition of Scotland's Community Empowerment Act (2015) can be realised in Glasgow will undoubtedly depend on the extent to which this legislation opens greater opportunities for activism, particularly within more disadvantaged areas. Whilst the Act has a built-in cognisance that participation can increase inequality and has consequently made tackling inequality a target for community participation (Scottish Government, 2017), the evidence from Glasgow's communities suggests that this will remain a challenging goal unless much wider action is taken to address the underlying patterns of inequality which form the backdrop for community activism.

\section{References}

Barnes M, Newman J, Knops A and Sullivan, H (2003) Constituting "the public" in public participation. Public Administration 81: 379-399.

Batty E, Beatty C, Foden M, Lawless, P., Pearson, S. and Wilson, I. (2010) The New Deal for Communities Experience: A final assessment. London: DCLG.

Blake G, Diamond J, Foot J, Gidley, B., Mayo, M., Shukra, K. and Yarnit, M. (2008) Community engagement and community cohesion. Water. York. York: Joseph Rowntree Foundation.

Boaden N, Goldsmith M, Hampton W, and Stringer, P. (1981) Public participation in local services, Harlow: Longman.

Brodie E, Cowling E, Nissen N, Paine, A., Jochum, V. and Warburton, D. (2009) Understanding participation: A literature review. London: Involve. 
Bynner C. (2017) Intergroup relations in a super-diverse neighbourhood: The dynamics of population composition, context and community. Urban Studies 56(2): 335-351.

Clapham, D., Kintrea, K. and Kay, H. (1996) Direct democracy in practice: the case of 'community ownership' housing associations, Policy and Politics, 24(4), pp. 359-374.

Cooke B and Kothari U. (2001) The case for participation as tyranny. In: Cooke B and Kothari U (eds) Participation: The new tyranny? London: Zed Books.

Crisp R, McCarthy L, Parr S and Pearson, S. (2016) Community-led approaches to reducing poverty in neighbourhoods: A review of evidence and practice. Sheffield: Centre for Regional Economic and Social Research, Sheffield Hallam University \& Joseph Rowntree Foundation.

Dahrendorf R. (1968) Society and democracy in Germany, London: Weidenfeld \& Nicolson.

Dean RJ. (2017) Beyond radicalism and resignation: the competing logics for public participation in policy decisions. Policy \& Politics 45: 213-230.

Escobar O. (2017) Pluralism and Democratic Participation: What Kind of Citizen are Citizens Invited to be? Contemporary Pragmatism 14: 416-438.

European Union. (2011) Community-led local development. Brussels: European Union.

Flint J. (2004) Reconfiguring agency and responsibility in the governance of social housing in Scotland. Urban Studies 41: 151-172.

Gaventa J. (2006) Finding the spaces for change: A power analysis. IDS Bulletin 37: 23-33.

Glasgow Centre for Population Health. (2017) Understanding Glasgow - The Glasgow indicators project. Available at: http://www.understandingglasgow.com/.

Glasgow City Council. (2016) Oatlands Regeneration. Glasgow: Glasgow City Council.

Gomme, A.H. and Walker, D (1968) Architecture of Glasgow. London: Lund Humphries

Green J and Chapman A. (1992) The British Community Development Project: Lessons for today. Community Development Journal 27: 242-258.

Hancock L, Mooney G and Neal S. (2012) Crisis social policy and the resilience of the concept of community. Critical Social Policy 32: 343-364.

Hastings, A., McArthur, A., McGregor, A (1996) Less than Equal: Community Organisations and Estate Regeneration Partnerships, Bristol: The Policy Press

Imrie R and Raco M. (2003) Community and the changing nature of urban policy. In: Imrie R and Raco M (eds) Urban Renaissance? New Labour, community and urban policy. Bristol: Policy Press.

Jones P and Evans J. (2013) Urban Regeneration in the UK. 2 ed. London: SAGE Publications Ltd. 
Kearns A, Wright V, Abrams L and Hazley, B. (2019) Slum clearance and relocation: a reassessment of social outcomes combining short-term and long-term perspectives. Housing Studies 34(2): 201-225.

Lavalette, M and Mooney, G. 2000 Class Struggle and Social Welfare. London: Routledge

Lee C, McQuarrie M and Walker E. (2015) Democratizing Inequalities: Dilemmas of the New Public Participation. New York: NYU Press.

Leslie, C. (2016) Disappearing Glasgow: A photographic journey. Glasgow: Freight Books

Maloney W, Smith G and Stoker G. (2000) Social capital and urban governance: Adding a more contextualised 'top-down perspective'. Political Studies 48: 823-841.

Matthews P and Hastings A. (2013) Middle-Class Political Activism and Middle-Class Advantage in Relation to Public Services: A Realist Synthesis of the Evidence Base. Social Policy \& Administration 47: 72-92.

McKee, K. (2007) Community ownership in Glasgow: the devolution of ownership and control or a centralizing process? European Journal of Housing Policy, 7(3), pp. 319-336.

McWilliams C, Johnstone C and Mooney G. (2004) Urban Policy in the New Scotland: The Role of Social Inclusion Partnerships. Space and Polity 8: 309-319.

Mooney, G., Poole, L. (2005) Marginalized voices: resisting the privatization of council housing in Glasgow, Local Economy, 20(1), pp. 27-39

ODS (2013) Govanhill Neighbourhood Audit. Glasgow: ODS Consulting

Parker G and Street E. (2015) Planning at the neighbourhood scale: localism, dialogic politics, and the modulation of community action. Environment and Planning C: Government and Policy 33: 794-810.

Peck J. (2012) Austerity urbanism. City 16: 626-655.

Plant R. (1974) Community and ideology: An essay in applied social philosophy, London: Routledge \& Kegan Paul.

Rolfe S. (2016) Divergence in Community Participation Policy: Analysing Localism and Community Empowerment Using a Theory of Change Approach. Local Government Studies 42: 97-118.

Rolfe S. (2018) Governance and Governmentality in Community Participation: The Shifting Sands of Power, Responsibility and Risk. Social Policy and Society 17(4): 579-598.

Ryfe D and Stalsburg B. (2012) The Participation and Recruitment Challenge. In: Nabatchi T, Gastil J, Leighninger $\mathrm{M}$, et al. (eds) Democracy in Motion: Evaluating the Practice and Impact of Deliberative Civic Engagement. New York: Oxford University Press.

Scottish Government. (2014) Community Councils. Available at: http://www.scotland.gov.uk/Topics/Government/PublicServiceReform/CommunityCouncils. 
Scotland. (2015) Community Empowerment (Scotland) Act. Edinburgh: Scottish Government.

Scottish Government. (2017) The Community Empowerment (Scotland) Act 2015 - A summary. Edinburgh: Scottish Government

Somerville P. (2011) Understanding community: Politics, policy and practice, Bristol: Policy Press.

Steiner AA and Farmer J. (2018) Engage, participate, empower: Modelling power transfer in disadvantaged rural communities. Environment and Planning C: Politics and Space 36: 118138.

Tonnies F. (1955) Communities and association, London: Routledge \& Kegan Paul.

UK. (2007) Local Government and Public Involvement in Health Act. London: HMSO.

UK. (2009) Local Democracy, Economic Development and Construction Act 2009. London: HMSO.

UK. (2011) Localism Act. London: HMSO.

United Nations. (2008) People matter: Civic engagement in public governance. New York: United Nations.

Watkins HM. (2017) Beyond sweat equity: Community organising beyond the Third Way. Urban Studies 54: 2139-2154. 